\title{
Seojeon Byungwon, Jutlandia, and NORMASH: UN's Scandinavian Allies at the Korean War and Beyond (1950s-1960s)
}

\author{
David W. Kim ${ }^{1,2} \cdot$ Heung-Sook Yang ${ }^{3}$
}

Received: 17 March 2021 / Accepted: 16 June 2021 / Published online: 1 September 2021

(C) The Author(s), under exclusive licence to Springer Nature B.V. 2021

\begin{abstract}
The Korean War (1950-1953) was one of the most calamitous and brutal wars in modern history. It was fought by the post-colonial people of the peninsula, and it culminated in the creation of two ideologically opposed states, but the three years' military clash in East Asia (or the Far East) is often labelled simply as a "Forgotten War" in the West including North America. The ensuing ethnic division has been interpreted through the various geopolitical lenses of military strategy, politics, international relations, and power games. What about the situation of casualties? Which particular nations in the United Nations (UN) dispatched medical aid for the treatment of war victims? How did the Scandinavian allies participate the non-European war? What were their unique characteristics among non-military supporting nations? What legacy they left for the post-war Koreans? This paper explores the militaryhistorical backgrounds by which each of the following Northern European nation, namely, Sweden, Denmark, and Norway, decided to send unarmed skilled personnel to aid South Korea. The paper argues the social voluntarism of the neutral group in the critical insight that the field activities of Swedish Seojeon Byungwon, Danish Jutlandia, and Norwegian NORMASH individually promoted the Red Cross spirit of advanced humanitarianism on the top of mandatory duty, in giving special attention on children (orphans), women, civilians, POWs, and medical education, as well as the post-war collaboration for the initial Korean public health system in the 1960s.
\end{abstract}

\footnotetext{
The sources of this research include the official documents (of the United Nations, Sweden, Denmark, Korea, and Norway), reports of Red Cross activities, individual testimonies of medical workers, memories of Korean people, and newspapers from local and national archives, museum, libraries, and galleries. Since this paper presents various data about the casualty number of the Korean War, some might be different than other sources excluded. The Revised Romanisation (RR) of Korean is generally applied unless indicated for McCune-Reischauer Romanisation.
}

This research has been supported by the Korea Foundation (KF) and the Academy of Korean Studies (AKS), Korean government.

David W. Kim

davidwj_kim@yahoo.co.uk

1 Australian National University, Canberra, Australia

2 Kookmin University, Seoul, South Korea

3 Pusan National University, Busan, South Korea 
Keywords Korean War · Pusan · NORMASH · Seojeon Byungwon · Jutlandia $\cdot$ Red Cross Introduction

When the 75,000 soldiers of the North Korean people's army came down across the 38th parallel, the Security Council of the United Nations was altered and demanded that North Korea immediately cease their acts of hostilities [124, 125]. The UN's Resolutions 83, then, encouraged the member states to provide assistance to South Korea on June 27, 1950 [33, 139]. The international organization established a unified command led by the USA [139]. The war of ideas was brutal and brought a huge number of casualties. The population of North Korea, according to Eberstadt, was about 9.62 million in 1949 [22]. In contrast, South Korea was estimated to have a population of 20 million [4]. The total causality rate of civilians was approximately $2-3$ million, which is generally considered larger than the casualties of the Chinese Civil War (1 million: 1927-1949) and of the Vietnam War (2 million: 1955-1975) [16, 55]. South Korea witnessed about 990,968 ordinary people directly affected as 373,599 were killed, 229,625 wounded, and 387,744 abducted/missing. It was worse to North Korea, for an estimate of 1,550,000 were killed or wounded (est.) [91].

While such data can only present a portion of the wars true fierceness, the United Nations Memorial Cemetery in Korea (UNMCK) indicates that the UN allies sent 1,957,733 soldiers during the Korean War [128, 138]. An even larger number of Chinese $(2,970,000)$ and Soviet Union (SU: 72,000) soldiers were drawn to support North Korea's military power, despite the relationship between China and SU that was not friendly, but competitive and suspicious to each other $[59,126] .{ }^{1}$ The Chinese Government in 2010 updated the official tally of their losses in the Korean War to 383,500 wounded, 25,621 missing (people captured and defected), and 183,108 dead [65]. Soviet Union lost 299 people (mainly pilots) along with 335 destroyed planes [62]. ${ }^{2}$ The South Korean Ministry of National Defence reported that the total number of North Korean casualties during the peninsula war is 229,849 wounded, 91,206 missing, and 294,151 dead [121]. Meanwhile, South Korea experienced less missing (24,495 MIA and 8,343 POWs) and death $(137,889)$ than North Korea but more soldiers were wounded $(450,742)[33,91]$.

The total number of casualties for the UN allies was about 776,360 people (Fig. 1). Among them, half of a million UN allies were wounded (555,022); 28,611 were missing in action while 14,158 were taken away to North Korea as POWs [64, 128]; 178, 569 soldiers died and 2,309 of them were buried at the UNMCK in Pusan (the Provisional Capital of South Korea). With the exception of the USA and South Korea, the UK $(1,078)$ and Turkey $(741)$ lost the highest number of soldiers. Australia (1,216), Canada (1,212), France $(1,008)$, the UK $(2,674)$, Turkey $(2,068)$, and Thailand $(1,139)$ were critically damaged with over 1,000 wounded soldiers. The UK (179) and Turkey (163) had the most MIA (missing in action) soldiers not counting the USA and South Korea. Fortunately, New Zealand, Thailand, Luxembourg, Ethiopia, and Norway did not have any POWs during the Korean peninsula war of East Asia. Given the long list of casualties, the question must be asked as to who provided medical aid for these casualties? What was the political reason or primary motivation of the Scandinavian

\footnotetext{
${ }^{1}$ North Korean Army strength peaked in October 1952 at 266,600 men in eighteen divisions and six independent brigades.

${ }^{2}$ During the Korean War, 72,000 Soviet troops (among them 5,000 pilots) performed along the Yalu River (압 록강) in Manchuria, China.
} 


\begin{tabular}{|c|c|c|c|c|c|}
\hline UN Allies & Total causality & Wound & MIA & POW & Death \\
\hline South Korea & 621,479 & 450,742 & 24,495 & 8,343 & 137,899 \\
\hline U.S.A & 137,250 & 92,134 & 3,737 & 4,439 & 36,940 \\
\hline United Kingdom & 4,908 & 2,674 & 179 & 977 & 1,078 \\
\hline Australia & 1,584 & 1,216 & 3 & 26 & 339 \\
\hline Netherlands & 768 & 645 & - & 3 & 120 \\
\hline Canada & 1,557 & 1,212 & 1 & 32 & 312 \\
\hline New Zealand & 103 & 79 & 1 & - & 23 \\
\hline France & 1,289 & 1,008 & 7 & 12 & 262 \\
\hline Philippines & 398 & 229 & 16 & 41 & 112 \\
\hline Turkey & 3,216 & 2,068 & 163 & 244 & 741 \\
\hline Thailand & 1,273 & 1,139 & 5 & - & 129 \\
\hline Greece & 738 & 543 & - & 3 & 192 \\
\hline South Africa & 43 & - & - & 9 & 34 \\
\hline Belgium & 440 & 336 & 4 & 1 & 99 \\
\hline Luxembourg & 15 & 13 & - & - & 2 \\
\hline Colombia & 639 & 448 & - & 28 & 163 \\
\hline Ethiopia & 657 & 536 & - & - & 121 \\
\hline Norway & 3 & - & - & - & 3 \\
\hline
\end{tabular}

$※$ Death number includes those who died during wounded, MIA, and POW.

※ Korea POW number includes those from exchange program and additionally repatriated POWs.

Fig. 1 Number of UN's casualties during the Korean War (The date is from Ministry of National Defense of Republic of Korea (2013). "Casualties of Korean War (in Korean)," archived from the original document)

allies to involve the Korean War? How did Sweden, Denmark, and Norway uniquely conduct their non-military operation? How did they cooperatively involve for the post-war project of the National Medical Centre (NMC) in Seoul?

\section{UN's Medical Allies for the Korean War}

The episodes of the $\mathrm{M} * \mathrm{~A} * \mathrm{~S} * \mathrm{H}$ at the TV show did not often display the strategical aspects of combat in the Korean War, but the importance of treating casualties is drily demonstrated $[25,3,11,23,24,33,34,47,119,127,141]{ }^{3}$ In this regard, the Mobile

\footnotetext{
${ }^{3}$ The Korean War began to bring people's attention, when Richard Hornberger, who was a Korean War medical veteran worked in the MASH 8055 (Mobile Army Surgical Hospital: the first MASH arrived in Korea), wrote a novel called, MASH: A Novel about Three Army Doctors in 1968. The popularity of the war fiction inspired making a film, $\mathrm{M} * \mathrm{~A} * \mathrm{~S} * \mathrm{H}$. The American "black comedy" war film released by the 20th Century Fox, was one of the biggest films of the era and became the winner of the "best adapted screenplay" award and "the Palme d'Or (highest prize)" award at the Cannes Film Festival (Festival international du film). Further, the war film was given the Golden Globe Award for best motion picture in 1971. The high reputation that the film $\mathrm{M}^{*} \mathrm{~A} * \mathrm{~S} * \mathrm{H}$ received, not only remained in North America but spread to the UK, Australia, and European nations. The 20th Century Fox then launched a television series. The TV show was based on the 4077 MASH in Uijeongbu (의정부), South Korea, and ran for over eleven years, from 1972 to 1983. The memories of $\mathrm{M}^{*} \mathrm{~A} * \mathrm{~S} * \mathrm{H}$ symbolically represent the field image of the US Army Medical Corps, which operated about ten MASHs during the Korean War.
} 
Army Surgical Hospital (MASH) units "were designed to keep pace with combat units during the time of war, providing immediate, lifesaving care to casualties" [56]. The origin of the MASH is related to the narrative of "Camp Letterman" in 1862, in which the Battle of Gettysburg left 20,000 soldiers wounded during the American Civil War (1861-1865). Among them, 4,217 severely injured soldiers had to remain on the battle field where medical service was provided to them. The medical strategy of Dr. Johnathan Letterman, with the involvement of medical personnel, volunteer nurses, and locals, contributed to the making of an ideal battlefield facility [2]. The MASH organization officially emerged at the end of the World War II (23 March 1945) and was based on the concept that "the full hospital could be broken down and loaded into trucks along with hospital staff' [142]. ${ }^{4}$ The method was developed with the notion that when a patient was stable, he would be taken to a semi-mobile hospital which would be capable of longer-term care. "The next stop was a permanent field hospital, a station hospital, or a hospital ship" [35] followed by evacuation to another safe region or country.

When the Korean War occurred, $16 \mathrm{UN}$ member states participated in helping to safeguard international peace and security. For most of them, it was the first time [92], ${ }^{5}$ and they confronted the environmental obstacles of the Korean weather, food, and commanding system. While the USA had their own MASH units [13,5, 8, 24, 88, 144, $146],{ }^{6}$ six nations also dispatched medical units by their political reason of international relations $[6,147] .{ }^{7}$ They were positioned under the command of the Eighth US Army in Korea (EUSAK). ${ }^{8}$ India, which had a strong influence of the United Nations Security Council in the late 1940s and early 1950s, deployed the 60th Parachute Field Ambulance. From November 1950, the Indian MASH was assigned in various places near the battle fields including Pyongyang (평양), Gapyeong (가평), Munsan (문산), and Daegu (대구). They reported of serving about 20,000 inpatients and 195,000 outpatients [132]. Their efforts are depicted through the illustration of "the Bucket Brigade (양동이부대)," who had to carry the water of the Daedong River (대동강) to the refuge train by which they evacuated casualties [13, 7]. Italy, as non-UN member, supported South Korea by dispatching the 68th Red Cross hospital, with the help of a transport ship. Their endeavor, caring 7,250 inpatients and 222,885 outpatients in the Yeongdeungpo (영등포) region of Seoul, was recognized by the United Nations as being valuable enough to qualify Italy as an official member of the international organization in 1955 [108]. Germany, one of the principal agents of World War II, also quietly set up a nonmilitary hospital in Pusan at the time the war was about ending in May, 1953. They

\footnotetext{
${ }^{4}$ The system was created in the way that the MASH should be located within 20 minutes of the front lines.

5 The material supplies of about 40 nations psychologically were great encouragement.

${ }^{6}$ Since there are already many sources on the American MASH, this paper will focus on the character and achievement of other European medical forces at the Korean War.

${ }^{7}$ The six nations include India, Italy, Germany, Sweden, Demark, and Norway. Young additionally argued the medical involvement of Israel.

${ }^{8}$ Their operation was more small-scale in comparison to the US operation.

${ }^{0}$ The German Red Cross hospital was operated by 80 doctors and nurses with 21 Korean medical staff. The medical service was contributed to 21,562 inpatients and 227,250 outpatients until 1959.
} 
mainly cared the post-war casualties [14]. ${ }^{9}$ However, the immediate medical works of the Scandinavian allies (Sweden, Denmark, and Norway) were more remarkable than the post-war participated nation ${ }^{10}$ as the spirit of "voluntary humanitarianism" "was commonly implemented by the Scandinavians in order to provide aid in all kinds of situations of exigency, including vulnerable children, civilians, POWs, and medical education on the top of regular calls for wounded soldiers. ${ }^{12}$ They were originally called without proper training, but their commitment progressively convinced their nations, UNKRA (the United Nations Korean Reconstruction Agency), and Korean government for the post-war collaboration for the initiation of Korean public medical system in the 1960s (Fig. 2)

\section{Swedish Seojeon Byungwon}

Then, how were the activities of Sweden different at the Korean War? How did Koreans remember their efforts? While the three Scandinavian allies together sent non-military forces from Red Cross organizations, ${ }^{13}$ (the Kingdom of) Sweden, a permanent neutral nation, was the first country to make a decision for a humanitarian aid for the Korean War. ${ }^{14}$ The Northern European nation politically evaded the registration of the North Atlantic Treaty Organization (NATO), which was a product of US security interests at the end of the World War II [12], but the largest contingent of Swedish medical unit based in Pusan from September 1950 for eight years. Shortly after the outbreak of the war, they established a mobile field hospital at the site of Pusan Commercial High School $[98,109] .{ }^{15}$ The major step in establishing an international relationship between Korea and Sweden was initiated by the involvement of the Swedish Red Cross Hospital (SRCH) in the Provisional Capital of South Korea (during August 18-October 27, 1950 and January 4, 1951-August 14, 1953). The SRCH was then known as Swedish Seojeon Byungwon (서전병원, 瑞典病院) among local people (Fig. 3).

The Battle of the Pusan Perimeter (부산 교두보전투) that was around the cities of Daegu, Masan, Pohang, and the Nakdong River was a large-scale engagement between

\footnotetext{
${ }^{10}$ The numbers of operations and out-patient treatment performed by the German hospital is quite similar to the Scandinavian Red Cross cases, and they carried on the care of the blood bank that Sweden had created. However, the German involvement was much later and the Korean War was less tension and hazard. Their motivation, as a defeated nation of World War II (1939-1945), was not fully seen as earnest, but more political for the future relationship with the United Nations and the North Atlantic Treaty Organization (NATO).

${ }^{11}$ The concept of "voluntary humanitarianism" in this paper implies the genuine efforts of personal dedication through sharing time, skills, and money beyond legal obligation at a war or dangerous situation. This is the committed behavior going extra miles even under life threat for those who are marginalized or less privileged. ${ }^{12}$ The functional differentiation between official (state sanctioned) aid and non-governmental aid (e.g., Red Cross) can be generally comprehended in the perspective that the purpose of the former is about rescuing own casualties, while the latter concerns the health welfare of humanity disregarding the social status of people.

${ }^{13}$ The Red Cross of each Scandinavian ally played an important role at the Korean War as providers of medical and other assistance, for there was no certain medical agency in the military sector of the era. The basic neutrality principle of the Red Cross was appropriate for all victims of allies' army, enemy, civilians, children, and women.

${ }^{14}$ Sweden, with Ireland, Malta, Cyprus, Finland, and Austria, did not join the North Atlantic Treaty Organization (NATO) after the Second World War.

${ }^{15}$ Sweden had 176 volunteers from 600 applications.
} 


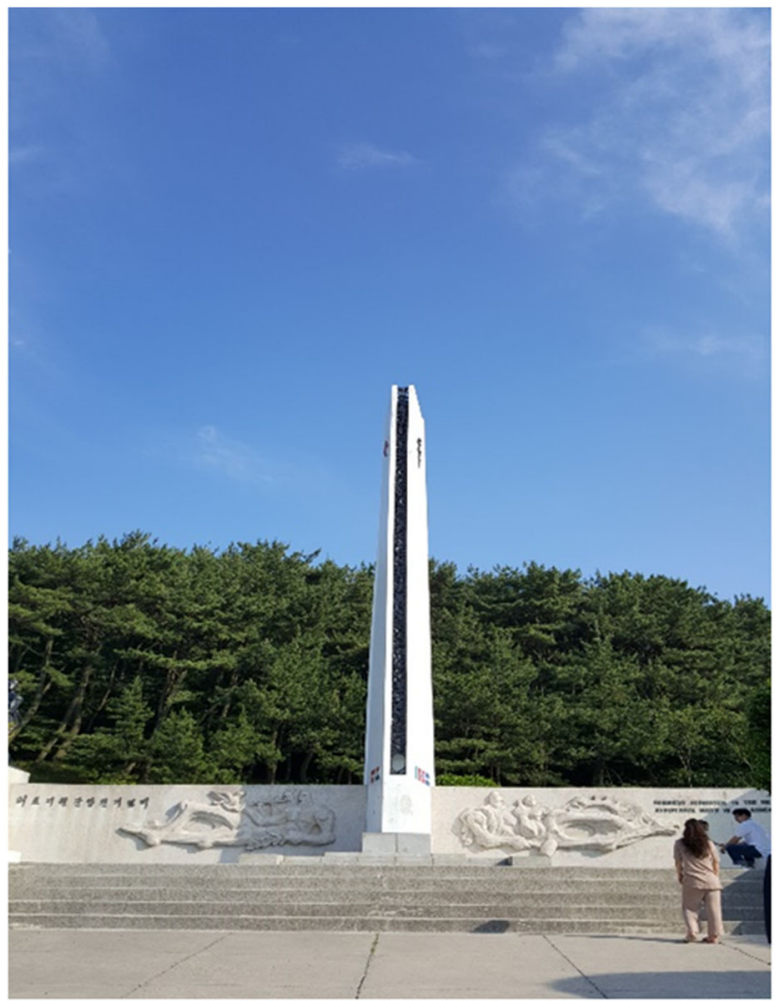

Fig. 2 Monument for UN's Medical Allies in Pusan (C)Heung-Sook Yang

the United Nations Command (UNC) and the North Korean forces from August 4 to September 18, 1950 [110]. The signal that victory was at hand for the UNC was when North Korea was undermanned and poorly supplied. Lack of naval and air support caused double the damage to the North Korean army by the time that General Douglas MacArthur (1880-1964) recommended a unique landing at Incheon (인천), near Seoul, well over $160 \mathrm{~km}$ behind the enemy lines [129]. Meanwhile, the SRCH was a unit among the EUSAK, who "exercised its influence ... through its liaison officers and other local channels" [99].

The SRCH was composed with two wards, 16 patient rooms, a consulting room, and an operation room. The schoolyard was used for nurses' accommodations, patients' rooms, and a cafeteria. They had 92 people for the medical team, while 76 people were working as administration staff with one minister. ${ }^{16}$ They also employed locals for cleaning, laundry, security, and chores. The work of Swedish Seojeon Byungwon is reflected in a medical statistic that the number of hospital visitors was about 225,000 people. The 200 bed mobile field hospital was planned to relocate to Heungnam (흥남) and then Wonsan (원산), north of the 38th parallel [90]. ${ }^{17}$ The plan, however, was rescheduled by the change of the war situation under Chinese intervention in approximately November-December of 1950. The SRCH developed their medical capability

\footnotetext{
${ }^{16}$ See Swedish Red Cross, Personal Vid Svenska Sjukhuset I Korea (Stockholm).

17 The number of bed was increased into 350 .
} 


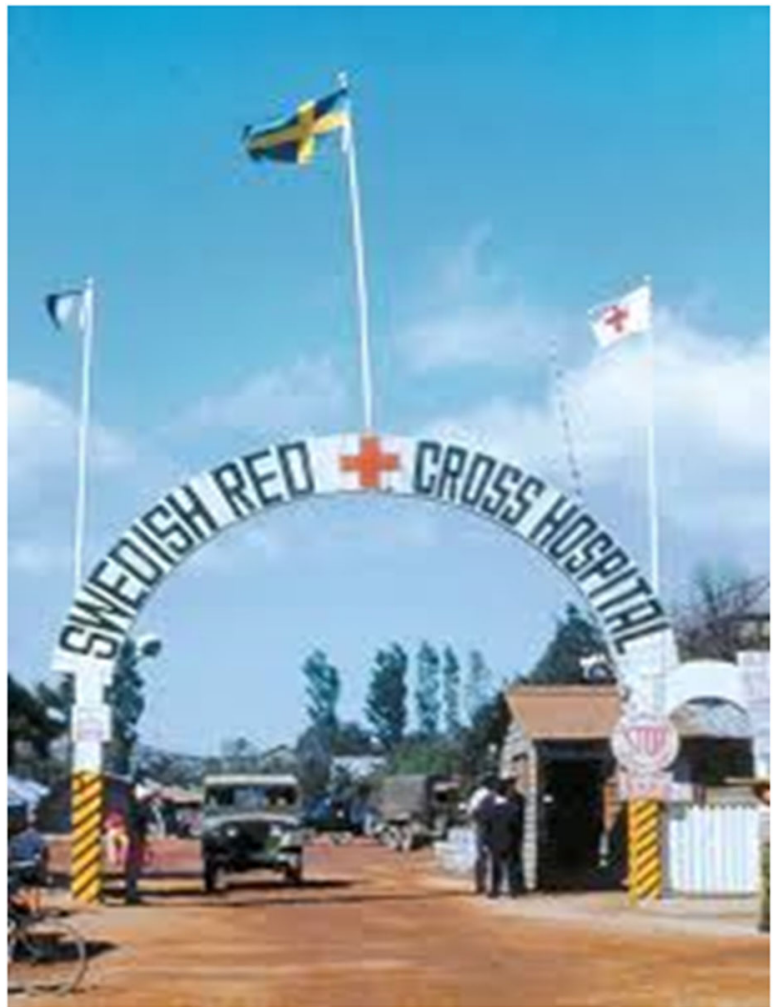

Fig. 3 Swedish Seojeon Byungwon in Pusan, public domain

based on humanitarian aid for enemy casualties. In this regard, they treated 69 North Korean POWs in October, 1950, who were in serious "condition with suppurations and maggot-infested, week-old wounds" [100].

The peninsula war occurred in the 38th parallel between January and June 1951 and then armistice negotiations began on 10th July 1951 at Kaeseong (개성). Such a continued pattern led the war in a stalemate between July 1951 and July 1953. During the constant and continuous nature of combat, the $\mathrm{SRCH}$, as an evacuation hospital, launched a campaign for the medical care of the civilian populace, for the Korean War hit civilians the hardest and Pusan experienced a steady stream of refugees who were in urgent need of medical attention [101]. Their autonomous outreach, on top of regular duty, created a partnership with local hospitals. Swedish doctors and nurses regularly visited partner hospitals to care for patients and advise the Korean personnel. Local patients were often transferred to the Seojeon Byungwon for surgery [102]. Rolf Kaijser's narrative from Monthly Report SRCH implies the military policy of limited support for civilian patients, but they used a separate Korean kitchen for the new civilian patient group [51]. The Swedish Seojeon opened an unofficial polyclinic, which eventually gave opportunities to relatives of the Korean hospital personnel, civilian and military organizations, and institutions around Pusan. The Institute for Military History (IMH) demonstrated the SRCH's achievement for civilian casualties during the thirteen months (from June, 1951 to June, 1952): 900 people were 
hospitalized, and 7,800 people got radio graphic inspection [46]. The Seojeon Byungwon was permitted by the EUSAK to have 125 beds for civilian use in September 1952. Another 40 beds were for child treatment in the following year. The Swedish hospital additionally set up a mobile children's polyclinic, led by their pediatrician. The medical outreach even gave treatment to some of the numerous orphanages $[42,130] .{ }^{18}$

The post-Korean war era witnessed more humanitarian projects that were launched by the Seojeon Byungwon until 1958. When Korea was at the stage of de facto peace, the Swedes spontaneously transformed into a type of a civilian hospital where major patients were general public, albeit still partly a military organization. The official policy for wounded soldiers was terminated in 1955 [45]. The Swedish hospital was then relocated to Pusan National Marine University (국립부산수산대학교, 國立釜山水産 大學校 $)^{19}$, which provided a more substantial space, accommodating up to 750 beds. They also possessed the biggest blood bank in Korea, which provided 5,870 pint in a single year. ${ }^{20}$ Many patients of the polyclinic were children from other hospitals in Pusan and around the region. The medical activity of pediatrics continued through 1955 and 1956, while a 40-bed surgical ward closed down and the size of the tuberculosis ward was reduced [103]. The pediatric work was developed in that doctors and nurses regularly visited more than ten orphanage houses, covering 2,500 children. The attempts at teaching the facility staff to take better care of the sick children were an extra educational activity that they applied to long-term management [104]. The City History Compilation Committee of Busan (CHCCB) records the numbers of orphanages in Pusan as 4,044 (1952), 4,032 (1954), and 4,704 (1957) [15]. Their weekly visitation to the Wooam-dong Public Health Clinic (적기보건진료소) of a refugee settlement was often about antibiotic treatment in the case of infections [42].

The Seojeon Byungwon also performed Mantoux screening tests on 61,172 people for diagnosing tuberculosis, since the disease had spread nationwide in the post-Korean War era (to approximately 1.2 million people) [136]. They began inoculating infants with the BCG (Bacillus Calmette-Guérin) vaccine (24,983 children and adults) between 1956 and 1958, in cooperation with the Australian Il-Shin Women's Hospital [42, 131]. The voluntary campaign to underprivileged sections of the community motivated other foreign institutions, including the Baptist Hospital, the Maryknoll Hospital, the Children's Charity Hospital, and the German Hospital [148]. ${ }^{21}$ The Korean doctors were also educated in tuberculosis and parasite disease management. The Swedish Seojeon Byungwon had a further plan, establishing an orphanage or a care house for children of leprous parents as the welfare of the Yongho-dong (용호동)

\footnotetext{
${ }^{18}$ Sweden, as part of the Natural Nations Supervisory Commission (NNSC), also involved the process of the Korean Armistice Agreement (한국휴전협정). The items of the Korean Armistice Agreement to be discussed were (1) adoption of an agenda; (2) fixing a military demarcation line between the two sides so as to establish a demilitarized zone as a basic condition for the cessation of hostilities in Korea; (3) concrete arrangements for realization of a ceasefire and armistice in Korea, including the composition, authority, and functions of a supervisory organization for carrying out the terms of a truce and armistice; (4) arrangements relating to prisoners of war; and (5) recommendations to the governments of the countries concerned on both sides.

${ }^{19}$ The name of the University has been changed as Pukyong National University (國立釜慶大學校) in 1996.

${ }^{20}$ Foreign letters: Swedish Hospital in Korea, Journal of American Medical Association 6 (1956): 551-552.

${ }^{21}$ The Seojeon Byungwon was well known among the local people of Pusan as a major hospital where seriously injured civilians could be cured. A testimony of Huisu Yun (윤희수) mentions a related story, "Mother went to Pusan Seojeon Byungwon to admit my sister Huideok (희덕) (어머님은 熙德 同生을 다리고 釜山 서전 病院에 입원시키러 가셨다)."
} 
community, despite eventually dropping the project [149]. The Swedish medical team in Korea (SMTK) was progressively formed in Pusan, whose main purpose was pediatric and anti-tubercular services. The consultative work was conducted until October 1958 for the hospital affiliated with Pusan National University. The effort of the non-military humanitarian aid is also proved by the historical fact that Sweden was the first nation who adopted a big number of war orphans in the mid-1960s, followed by Denmark, Norway, Belgium, the Netherlands, Switzerland, France, and Germany $[21,54,60,89,105] .^{22}$

\section{Denmark's MS Jutlandia}

As Denmark had supported the UN peacekeeping program since 1948 [48, 143], they decided to agree on the resolutions $(83,84$, and 85) of the United Nations for South Korea. However, Denmark, the second Scandinavian nation, like Sweden, did not dispatch military forces despite American requests for combat troops. The political situation against the rising fear of Soviet military aggression and expansionist policies was a big pressure for Denmark [49, 116]. The hospital ship of the Red Cross, called MS Jutlandia, instead, represented their willingness and compassion for the people of the Korean peninsula (Fig. 4). The ship was built in 1943 as a combined passenger and cargo ship [93, 112]. ${ }^{23}$ The 8,500 ton ship that was previously used for transport between Copenhagen and Bangkok accommodated nine single and twenty-nine double staterooms. The dining room could seat seventy and included a smoking room, ladies lounge, bar, and a fore-deck swimming pool [29]. A dining room and play room were also provided for children $[97,30] .^{24}$

The supporting policy of the Danish Government in regard to the Korean War was unfolded by the transformation of the MS Jutlandia as a national medical aid (it costed about one million dollars) [113]. She secured four operation theatres and four hospital departments (surgical dept., internal dept., dental dept., and radiology dept.) with up to 356 beds, X-ray, eye and dental clinics, as well as laboratories, dispensaries, and special departments. Denmark sent about 100 medical staff: 15 doctors, 45 nurses, 30 corpsmen, and stretcher men in addition to the secretaries, a masseuse, laboratory assistants, the pharmacist, and a chaplain $[42,143] .{ }^{25}$ The ship additionally had a crew of about 100 men. The bulk of the hospital staff were mature and experienced people whose average age was around forty. The spirit of volunteerism was demonstrated in the example case of Captain Kai Hammerich who stepped down from his role as president of the Danish Red Cross for the mission to Korea. As the hospital crew had to handle soldiers, all of them were given military rank for their duty [37].

\footnotetext{
22 The (Swedish) Ministry of Health and Welfare (MHW) once mentioned that fewer than 30 abandoned Korean children were adopted in 1965, but the number was increased to 340 in 1970. This paper would not explore the details any more, but see the following references.

${ }^{23}$ Denmark was the same with Sweden, Norway, Germany, and Italy in sending Red Cross medical units to the war zone of Korea.

${ }^{24}$ Passenger spaces were ventilated by chilled or heated air. The ship provided 539,570 cubic feet $(15,278.9$ m3) capacity for cargo.

${ }^{25}$ Doctors and nurses were allocated four to a cabin.
} 


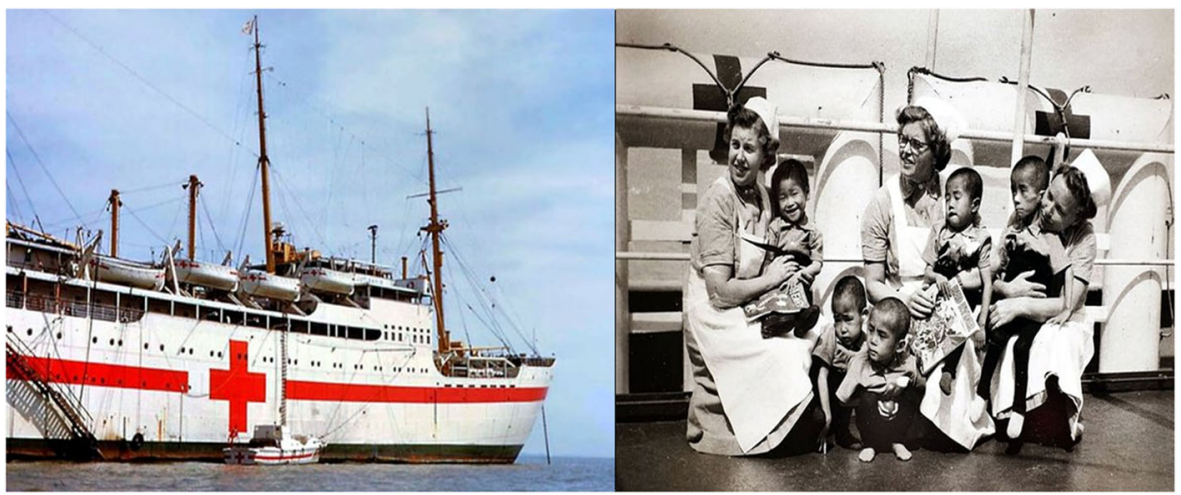

Fig. 4 MS Jutlandia hospital ship and wounded children [123]

Jutlandia (also known as Jeongmal byeongwon seon 정말병원선, 丁抹病院船) arrived in Pusan on 10 March 1951, when the war was intensely progressed around the 38 th parallel after the January-Fourth Retreat (1.4후퇴). The number of casualties was again increasing from the middle of the peninsula. Yet, the number of wounded on board was maintained as less than 100 to over 200 [37, 86], for they considered the standard of the selection especially in view of the badly injured patients [145]. Because the hospital ship kept a high international standard, some of the most difficult cases were sent to it. As a result, there were more surgical than medical patients, in particular neurosurgical patients. The Danish ship was the first marine hospital that treated Korean civilians alongside seriously wounded soldiers. The doctors and male nurses voluntarily helped at improvised first-aid stations [66]. The nature of a remarkable civilian orientation was seen in the fact that the local patients unofficially received limited aid, and in certain cases, were brought on board [84].

The non-official activity of humanitarian aid was extended to orphans for medical care. The concern of refugee children's health motivated to create a small children's department in a corner of the officer's ward. The Danish doctors likewise visited and assisted the American children's hospital (called Happy Mountains) on the outskirts of Pusan [9, 118]. The official permission was given for the treatment of civilians in July 1951, but the priority was still given to wounded soldiers. From November 1951, the policy was changed in favor of local nationalities: 100 beds were at the disposal of the local military hospitals, and 100 more could be utilized for civilians [50]. The Danish staff systematically educated Korean doctors to improve the standard of treatment. In this regard, Dr. Geukun Go worked on the Danish ship and had the overseas experiences at the children hospitals of Københavns Universitet (Denmark) and University of London (UK). He eventually became a pioneer of Korean pediatrics [41]. The local humanitarian work ashore continued with school education started in the children's department [140]. Like Swedish Seojeon Byungwon, Danish medical staff dedicated their free time to aid at operations in the ground hospitals that treated POWs [44].

The hospital ship received some British ambulance motorboats, a helicopter deck, and an eye clinic in August/September 1952. It then stationed in the Incheon bay (인천만), approximately $40 \mathrm{~km}$ from the battle fields [37, 87]. The war had reached a stalemate while the negotiation discussion of the Korean Armistice Agreement 
(한국휴전협정) was going on [10]. By using the helicopter deck, wounded soldiers could be on board in 20 minutes after they got wounded. The patients came directly from the front lines and the hospital ship was operating a 24-hour business on board. Yet, the crew found time to assist in the building a clinic ashore that could provide help to the poor and sick. During its service, the Danish hospital ship cared for 4,981 wounded allied soldiers from 24 different nations, as well as over 6,000 locals, including an unknown number of children (and orphans) [28, 31, 123]. The first South Korean President, Dr. Syngman Rhee, also received dental treatment on board [12, 50, 94]. ${ }^{26}$ Although the idea was not accepted by the North Koreans, the United Nations offered the MS Jutlandia as the venue for the negotiations of a truce [28, 32, 53]. On three separate occasions, the hospital ship transported wounded soldiers, POWs, and war dead out of the war zone to their country in August 1951, April 1952, and August $1953[57,58,96] .^{27}$

The data regarding military expenditures, according to Ringsmore, demonstrates the effort that Denmark gave to the Korean War. In detail, the national defense budget was increased by $250 \%$ in 1951 and the defense cost more than doubled from 1950 (1.7 GDP) to 1953 (3.7 GDP) $[85,117] .^{28}$ Jutlandia, a song by Kim Larsen, was a historical echo on the heroic achievement of the Danish medical ship [1, 52, 63]. The military and humanitarian role of the medical ship Jutlandia in the Korean War was praised among the local people in Denmark in 1986. Jutlandia was additionally featured in the 2018 Danish 6-part TV drama series "Sygeplejeskolen" (The New Nurses) [18, 135]. ${ }^{29}$ Thus, the voluntary Red Cross works of the hospital ship beyond political duty were not only critical for desperate Koreans but also remembered in the heart of Danish citizens.

\section{NORMASH: Korea Sisters}

How was the participation of Norway comprehended among the United Nations' allies? The Norwegian Government, which was also a neutral country, sent a Mobile Army Surgical Hospital (MASH) to support UN's work in June, $1950 .{ }^{30}$ Like Sweden and Denmark, this was the first experience the country involved in a war on foreign soil during the twentieth century [72]. The Norwegian Mobile Army Surgical Hospital (NORMASH), under the leadership of Herman Ramstad, was placed at Uijeongbu (의정부), approximately 12 miles north of Seoul (or 9 miles behind the front lines) (Fig. 5). The first non-American surgical hospital on the battle field was relocated two more times to Dongducheon (동두천; right on the 38th parallel) and to another location just over 2.5 miles away from where the battles were occurring $[38,73,75]$. Their official purpose was the same with normal MASHs, but they themselves were not military

\footnotetext{
${ }^{26}$ Kai Hammerich, the captain of the Danish Jutlandia was awarded a South Korea's Order of Merit (대한민국 장), the highest honor of South Korea in March 1952.

${ }^{27}$ Such as Belgium, Ethiopia, France, the Netherlands, Greece, Turkey, and England.

${ }^{28}$ It was known that the operation of the Jutlandia costed over four million dollars.

${ }^{29}$ Which depicted the innovative integration of male nurses into a Danish hospital training program.

${ }^{30}$ Norway used to be known as a country of neutrality, but when being taken by Nazi Germany during the Second World War, they were seeking alternative policies. They eventually became a founding member of the North Atlantic Treaty Organization (NATO) in 1949. Yet, the nature of neutrality in a non-official way lasted through the time of Korean War.
} 
experts. Rather, the Norwegian Red Cross represented their nation in a non-military way of humanitarian aid, for they had previous experiences of sending ambulances with trained nurses in four different conflicts such as the First Balkan War (19121913), the Finish Civil War (27 January-15 May 1918), the Second Italo-Ethiopian War (1935-1936), and the Winter War between Soviet Union and Finland (30 November 1939-13 March 1940). ${ }^{31}$

The NORMASH, under the EUSAK, was known as "the Orchard" as it was originally placed in a beautiful orchard [74]. The Norwegian field hospital was composed of tents alongside two corrugated iron buildings: a welfare building and a church [76]. With a staff of 83 (mainly nurses and doctors) and 60 beds (eventually extended to 200 beds), they treated about 90,000 casualties as well as 80,000 dental patients [39] from various nationalities: the US (36\%), South Korean (33\%), and British and Commonwealth soldiers (27\%) [68]. The medical chart proves that about eight surgeries per day were performed on average. A total of 9,600 patients were operated on at the field hospital over the total period of the Norwegian service [27]. Though numbers during a war period may not be often accurate, it was recorded that they had 14,755 inpatients and 55,950 outpatients [42]. Further, the Royal Norwegian Embassy in Seoul maintained that approximately $98 \%$ of the wounded who were brought there successfully survived and that $80 \%$ of them returned to active duty after treatment $[83,120]$.

By the time the cease-fire talks began between the three parties of the United Nations, North Korea, and China, the NORMASH offered services to civilians who could not reach a Korean hospital. For wounded children, the Norwegian hospital was more than a medical center, providing food, shelter, and a place to sleep. The work of the Norwegian humanitarian aid likewise reached for 172 North Korean and Chinese prisoners of war (POWs) [17]:

It has been peculiar to meet POW people. And it has been great fun to be able to speak to the Chinese prisoners. I feel so definitely that I am in the right place, and it's so strange feeling happy being able to give a little hand of help in a grey day. Again thank you, dear sister Ruth [113].

The situation reminded them of their past that when Norway was occupied by Nazi Germany in 1940-1945, Norwegian hospitals was requisitioned to nurse German soldiers [77]. ${ }^{32}$ Lockertsen, Fause, and Hallett all presume that such a situation indicates that the NORMASH was environmentally transformed from a Red Cross hospital, to a military hospital, and then to a "hybrid hospital" where all kind of war casualties were welcomed and treated [73, 80]. Many Norwegian men and women served: 111 nurses, 22 deacons, 80 surgeons, 5 dentists $[39]^{33}, 6$ pharmacists, 98 officers/ NCOs, and 294 privates $[17,67,120] .{ }^{34}$ Among them, the group of Norwegian nurses was known as "Korea Sisters," because of their volunteerism on the battle

\footnotetext{
$\overline{31}$ The voluntary organization that was founded in 1865 , provided free medical aid in war as well as the Army's Medical Services.

${ }^{32}$ Even the Conventions de Genève supported humanitarian treatment in war.

${ }^{33}$ Gudvin Sydness, Jon Borg, Bjørn Jostein Bakken, Hjalmar Straalberg, and Kjell Bjerkoe.
} 


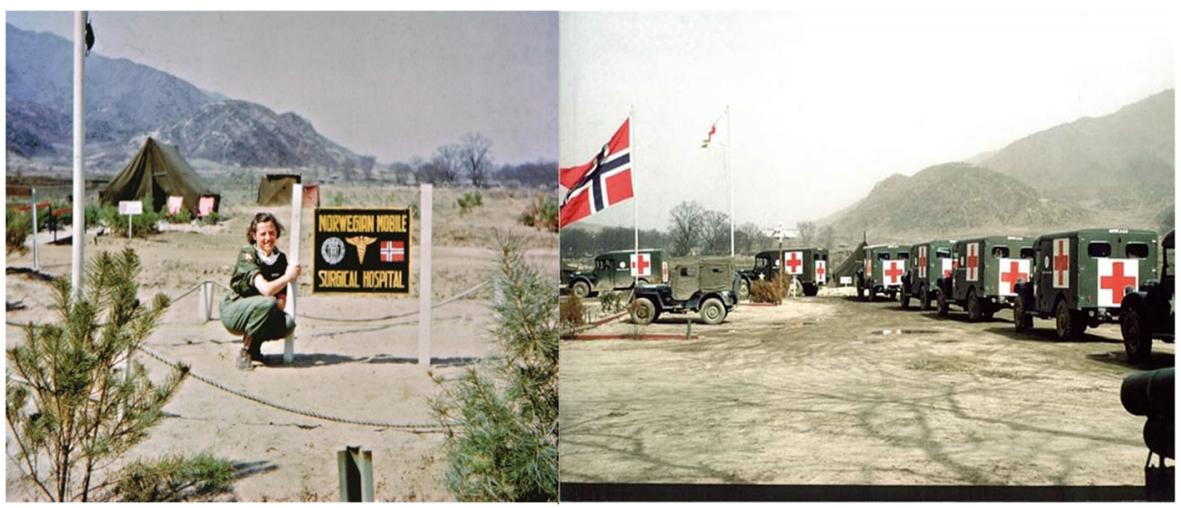

Fig. 5 NORMASH near the 38th parallel [61]

field. Since Norway never had a professional army nursing corps, the Red Cross nurses, like other Scandinavian allies, were given a military rank with the Red Cross emblem. Yet, most experienced nurses entered the Korean War with at least completing a threeyear educational program between 1930 and 1947 [69]. ${ }^{35}$ The total Norwegian nurses were divided as matrons (7\%), X-ray and laboratory nurses (13\%), ward nurses (21\%), and theatre nurses $(59 \%)$. The distribution implies that theatre nurses was the most demanded ones [68]. The nurses in the war autonomously involved the surgical procedure such as "triage, initiating blood transfusions, beginning penicillin regimens for those with open wounds, suturing, ligating vessels... resecting organs, dressing wounds, directing kidney dialysis, which was instituted by new technology" [43]. They also had to treat patients with war trauma as well as non-military social accidents. Since the US Army lacked trained theatre nurses, the trained nurses and technicians frequently assisted the surgeons of the external MASH operations [78, 122]. ${ }^{36}$

After the armistice in July 1953, the local people witnessed their role as more than running a hospital and providing nursing care but also offering support, resources, respite, and friendship to the local people looking for medical refuge [82]. The staff of the NORMASH kept their own blood bank for Koreans when the supply of bank blood ceased. It is numerically proved in the data that among 1,059 inpatients, 657 was civilians for the first half of 1954 and out of 11,697 polyclinic consultations, there were 5,956 civilians [81]. The Norwegian nurses launched a program to teach practical nursing in rural areas near the hospital, while the medical staff, including dentist, visited a regional leper village [40, 60]. Local nurses were employed and educated $[69,115]$. The friendly relationship between them eventually opened up more opportunities for Korean nurses for travelling overseas to receive further education and professional development [19]. DiMoia argues that the social tendency initiated a transnational migration in 1954-1963, which constituted "a special category of workers representing their nation in a variety of new settings and contexts, including West Germany, South

\footnotetext{
${ }^{0}$ According to the Royal Norwegian Embassy in Seoul, numbers are a bit different as 623 Norwegians served in Korea. A total of 191 were doctors and nurses, while 329 were officers and privates. There were about 4060 Koreans civilians and some American personal as well.

${ }^{35}$ Under 40 years old.

36 "All specialist nurses and ward nurses at the NORMASH was women, apart from a small number of fully trained male deacons."
} 
Vietnam, and the USA" [20]. The humanitarian mindset of the "Korea Sisters" was demonstrated in the personal attitude that they exhibited when they shared their supply of clothes with the new sisters for Koreans, especially clothes for toddlers [79, 114]. The voluntary motivation was carried on even after their service. Like Sweden, the NORMAS people cared for orphaned children. It led to the creation of an association called the "Norwegian Korea Foundation (Norsk Korea Forening)," which became a channel for Norwegian aid in the post-war Korean community as well as involving the adoption of children without parents [26, 120]. The culture of the NORMASH transferred into the project of the KORMASH (Korean Mobile Army Surgical Hospital) as a non-military medical hospital run by the Korean government when the social crisis of the MERS-CoV (Middle East Respiratory Syndrome) occurred in 2016 [134].

\section{Combined Program}

Geographically, the UN's Scandinavian allies did not have close relationship to communicate each other effectively. Denmark had a hospital ship floating around Pusan and Incheon harbors as well as travelling to Japan, Denmark, and other countries. Sweden was operating an evacuation hospital in Pusan, while the NORMASH under the US command was frequently relocated near by the war zone. When the Korean War was ending, Denmark's MS Jutlandia left Korea in August 1953. The Norwegian Mobile Army Surgical Hospital left in October 1954. The Swedish Red Cross Hospital (SRCH) remained until April 1957. Yet, among the six nations of the United Nations' allies who provided medical units, Denmark, Sweden, and Norway had discussed their humanitarian interest in the foundation of a nationwide medical aid for post-war Korea since June $1951[36,106] .{ }^{37}$

The joint Scandinavian project, with 1000 beds and educational opportunities, was initiated at the end of the Korean War (1953) [120]. ${ }^{38}$ The preliminary thought of a united hospital was officially agreed upon when Sweden, Norway, Denmark, the Republic of South Korea, and the United Nations Korean Reconstruction Agency (UNKRA) drafted a memorandum in establishing a medical center for training health personal [70, 95, 137]. While the UNKRA financially supported for the facilities including hospital wards, accommodation, and transport (\$2.4 million), the three Scandinavian nations contributed the sources of medical experts and equipments $(\$ 2$ million). The Korea government also provided the land and local workers $(\$ 0.97$ million) [96]. The National Medical Centre (NMC), an extension of the humanitarian project, was alternatively opened up in Seoul on 1 October 1958 on the former site of the Seoul Citizen Hospital (서울시립시민병원) [111, 137]. The new public hospital had a nursing school, library, operation rooms, wards, emergence facility, prescription chamber, pathology department, pharmacophora, etc. [96]. ${ }^{39}$

The joint medical staff from the three Northern European countries operated the NMC for ten years before handing it over to the Korean authorities and health care

\footnotetext{
37 There was the first official meeting with representatives of Demark, Sweden, Norway, the United Nations Civil Assistance Corps Korea (UNCACK), and the United Nations Korean Reconstruction Agency (UNKRA).

${ }^{38}$ However, the hospital started with 320 beds.

${ }^{39}$ As well as outpatient clinic, biochemistry and virus laboratories, nurse' rooms, and sterilizing room. They also kept the internal policy of charging only $25 \%$ from the total medical service fee.
} 
experts in 1968. The Scandinavian assistance was continued for three more years until 1971. A total of 367 Western doctors, nurses, and other personnel involved the medical development of the post-war nation. In particular, they opened up the three-month affiliation course for local nurses. The two weeks leadership course was for chief nurses. The certificate for six-month operation room experience was also officially issued. The courses of midwife and anesthesia over one year period were special to the students coming from all over the nation $[36,96]$. The Scandinavian experts were even invited to the local universities in Seoul and other regions to support clinical education. Thus, 134 Swedish, 94 Danish, and 139 Norwegian nurses, including nine former NORMASH nurses (including "Korea Sisters") [71], under the support of their governments [107], transferred advanced medical technology as a "spirit of humanitarianism" 40 over to the NMC leadership in a form of independence from the military. During the time between 1958 and 1969, they, with Korean staff, serviced 74,582 inpatients and 1,070,511 outpatients [96]. The Scandinavian Foundation (SF) eventually became the legacy of the friendship between Korea and the UN allies.

\section{Conclusion}

The geopolitical issue of the Korean peninsula has been going on since 1945, the year of colonial independence, but the sudden military action led to conflict and confusion in the international society in June 1950. Like 18 nations (including China and Soviet Union) who sent military forces, the medical support nations had political reasons of international relations. Nevertheless, they were not used or did not have professional military hospital facilities. The Korean War was the first time that they tried their medical methods or skills under the supervision of the EUSAK. Italy, as a non-UN member, and Germany, after World War II, cautiously dispatched non-military hospitals, whereas India was a brave MASH in sense of military duty. Meanwhile, the Scandinavian allies of the United Nations were individually distinct. The European nations of Sweden, Denmark, and Norway followed the military procedure of helping wondered soldiers as their mandatary obligation. ${ }^{41}$ Further, they, under the basic values of the Red Cross, resolutely extended the creative scale of humanitarian aid in supporting the non-political agenda of local health through the voluntary medical activities directed to the welfare of children, civilians, POWs, and education.

Swedish Red Cross firstly arrived when South Korea and the UN allies were strategically pushed down to the Nakdonggang River line ("the Pusan Perimeter": 4 August to 18 September 1950). The Swedish medical staff, though under the serious strain of the war, contributed extra support for a huge number of refugees in Pusan. They improved the health condition of children through supplying them with the BCG (Bacillus Calmette-Guérin) vaccination. The foundation of the Swedish Medical Team in Korea (SMTK) exhibited evidence of their volunteerism as well as the new culture of adopting war orphans. The hospital ship from Denmark played a similar role of

\footnotetext{
$\overline{40}$ The "spirit of humanitarianism" in this paper indicates the personal concern and voluntary dedication (time, space, money, skills, and ability) towards particular people or organization disadvantaged beyond regular duty or responsibility.

${ }^{41}$ Norway and Demark were officially founding members of NATO, but their humanitarian attitude was on the same direction with the medical volunteers from Sweden.
} 
humanitarian aid for refugee children. With the high standard of medical facilities, they provided systematic education for local doctors and nurses to improve their skills. ${ }^{42}$ The mobility of the MS Jutlandia not only helped soldiers in and around the Incheon harbor, they also created a children's department on board. The NORMASH looked externally similar to other MASHs, but internally, they were composed by non-military volunteers, whose patients, according to the testimonial records, almost all recovered safely whenever they reached the war zone hospital. In particular, the role of the "Korea Sisters (Norwegian nurses)" was well informed for war trauma care as well as teaching self-nursing skills for regional people. Their medical education challenged Korean nurses for further overseas study or experiences. Such a volunteerism from the three Scandinavian allies bore an international organization for the post-Korean war society. In particular, the collaborative commitment of Sweden, Denmark, and Norway to the National Medical Centre (NMC) became a role model for other nations as part of the post-war policy of the United Nations. The tradition of humanitarianism was handed down to the NMC, which became the foundation of the Korean public health system as well as a top actor in the response to COVID-19 in terms of both quarantine and prevention [133].

\section{References}

1. Abdominal og urologisk kirurgi, (1953). Ugeskrift for laeger 115 (24), 921-925.

2. Anonymous, (2015). Dr. Letterman's Primitive MASH Unit, America's Civil War 28 (3), 30-37.

3. Apel, O., and Apel, P. (1998). MASH: An Army Surgeon in Korea. Louisville: The University Press of Kentucky.

4. Armstrong, C-K (2010). The destruction and reconstruction of north Korea, 1950-1960, The AsiaPacific Journal 8, (51): 1-6.

5. Baker, M-S. (2012). Military medical advance resulting from the conflict in Korea, part ii: historic clinical accomplishments, Military Medicine 177 (4): 430-435.

6. Bandeoğlu, Z. (2019). United Nations' role in the Korean War (KORE SAVAȘI' NDA BIRLEȘMIȘ MILLETLER' IN ROLÜ), TURAN: Stratejik Arastirmalar Merkezi; Kars 11 (43), 373-379.

7. Barnes, R. (2013). Between the blocs: India, the United Nations, and ending the Korean War, Journal of Korean Studies 18 (2), 263-286.

8. Bellafairs, J. (2011). Women in the United States Military: An Annotated Bibliography. London and New York: Routledge.

9. Bom, F. (1952). Militærpsykiatriske indtryk fra koreakrigen): Fra det danske hospitalsskib jutlandia, Nordisk Psykiatrisk Medlemsblad 6 (4), 312-318.

10. Bom, F. (1952). Militærpsykiatriske indtryk fra koreakrigen): Fra det danske hospitalsskib jutlandia, Nordisk Psykiatrisk Medlemsblad 6 (4), 111-119.

11. Briley, R. (2015). (Review) detroit, Film and History 45 (1), 96.

12. Brocks, H. (1953). Jutlandia's organisatoriske placering, Ugeskrift for laeger 115 (24), 919-921;

13. Cha, V. (2009-2010). Powerplay: origins of U.S. alliances in Asia, International Security 34 (3), $158-$ 196.

14. Choi, H-S. (1996). Adenauer's security policy before and after the Korean War, Korean Journal of International Relationship 36 (2): 127-152.

15. City History Compilation Committee of Busan (2018). Pusan Sisa (Pusan City History) Vol., 1. Pusan: City History Compilation Committee of Busan.

16. Cumings, B. (2011). The Korean War: A History. New York: Modern Library.

\footnotetext{
$\overline{42}$ The meaning of "humanitarian aid" includes the voluntary activities of "transferring advanced medical technology" and "providing the systematic education to local medical staff."
} 
17. Dale, Det Norske Feltsykehus I Korea; Bakke, NORMASH-Korea I Våare Hjerter, 14-16.

18. det kroniske empyema, (1953). Ugeskrift for laeger 115 (24), 925-930.

19. DiMoia, J-P. (2017). Placing image and practice in tension: South Korean nurses, medical padagogy, and the Indiana university bloomington nursing program, 1958-1962, East Asian Science, Technology, and Society: An International Journal 11, 499-518.

20. DiMoia, J-P. (2017). Placing image and practice in tension: South Korean nurses, medical padagogy, and the Indiana university bloomington nursing program, 1958-1962, East Asian Science, Technology, and Society: An International Journal 11, 503.

21. Donnell, K-A. (2019). Orphan, Adoptee, and Nation: Tracing the Korean Orphan and Adoptee through South Korean and American National Narratives, A dissertation submitted to the University of California, Berkeley.

22. Eberstadt, N. (2017). Policy and Economic Performance in Divided Korea During the Cold War Era: 1945-91. Washington, D.C.: AEI Press.

23. Eder, R. (2001). $\mathrm{M}^{*} \mathrm{~A} * \mathrm{~S} * \mathrm{eH}$ on the rocks: a first novel is set in a hospital in Greenland for Korean War veterans, New York Times Book Review, 22.

24. Edward, P-M. (2006), the Korean War. Westport, Connection and London: Greenwood Press.

25. Emanuele, R-L. (2017). Memories of $\mathrm{M}^{*} \mathrm{~A} * \mathrm{~S} * \mathrm{H}$ by a real-Life MASH Doctor, Chicago Tribune, [Online] https://digitaledition.chicagotribune.com/tribune/article_popover.aspx?guid=48106c37-65ac461e-920c-74e0dc4d6979 (28 May 2021).

26. Eriksen, K-E-R. (2020). A great desire for children: the beginning of transnational adoption in Denmark and Norway during the 1960's, Genealogy 2020, 4(4), 104; 10.3390/genealogy4040104.

27. Florelius, Rapport fra Norges Røde Kors; Dale, Det Norske Feltsykehus I Korea, 67-68.

28. Foged, J. (1952). Jutlandia's 3. togt til Korea. I. Hospitalsskibets nuvaerende indretning og bemanding, Ugeskrift for laeger 114 (46), 1648-1649.

29. Foged, J. (1952). Jutlandia's 3. togt til Korea. II. Udrejsen, Ugeskrift for laeger 114 (48), 1743-1744.

30. Foged, J. (1953). Jutlandia's 3. togt til Korea. III. Mere om udrejsen, Ugeskrift for laeger 115 (2), 72-74.

31. Foged, J. (1953). Jutlandia's 3. togt til Korea. IV. I Japan,” Ugeskrift for laeger 115 (5), 189-191.

32. Foged, J. (1953). Jutlandia's 3. togt til Korea. VI. Arbejdet i Korea begynder, Ugeskrift for laeger 115 (8), 311-312.

33. Fox, L. (2018). Not Forgotten: The Korean War in American Public Memory, 1950-2017. Philadelphia, PA: A Dissertation Submitted to the Temple University.

34. Friedman, S-G. (2017). Korea, $\mathrm{M} * \mathrm{~A} * \mathrm{~S} * \mathrm{H}$, and the accidental pioneers of vascular surgery, Journal of Vascular Surgery 66 (2), 666-670.

35. Friedman, S-G. (2017). Korea, $\mathrm{M} * \mathrm{~A} * \mathrm{~S} * \mathrm{H}$, and the accidental pioneers of vascular surgery, Journal of Vascular Surgery 66 (2), 667.

36. Frydenlund, K. (1966). Norsk utenrikspolitikk i etterkrigstidens internasjonale samarbeid. Oslo: "Tidens ekko," NUPI, 112.

37. Fugate, R-T. (1953). The Jutlandia, Quantico 36 (3), 33-35, 80.

38. Guldseth, T. (1997). Koreakrigen: Korean War- the Korean War Veteran Journal of a Norwegian Dentist (Koreakrigen: 한국전쟁 - 노르웨이 치과의사의 한국전쟁 참전기-), Journal of the Korean Dental Association 35 (9), 698-699.

39. Guldseth, T. (1997). Koreakrigen: Korean War- the Korean War Veteran Journal of a Norwegian Dentist (Koreakrigen: 한국전쟁 - 노르웨이 치과의사의 한국전쟁 참전기-), Journal of the Korean Dental Association 35 (9), 698-703.

40. Guldseth, T. (1997). Koreakrigen: Korean War- the Korean War Veteran Journal of a Norwegian Dentist (Koreakrigen: 한국전쟁 - 노르웨이 치과의사의 한국전쟁 참전기-), Journal of the Korean Dental Association 35 (9), 702-703.

41. The Works of Dr Geukun Go, Gyeonghyang Newspaers (경향신문), 19 April, 1952.

42. Ha, B-H. (2017). Swedish Red Cross Hospital in the 1950s. Pusan: Pusan Metropolitan City and Pusan Cultural; Foundation.

43. Hallquist, D-L. (2005). Developments in the RN first assistant role during the Korean War, AORN Journal 82 (4), 644.

44. Hanghøj, D. (1993). Sygeplejerske på Jutlandia, Sygeplejersken 93 (8), 4-7.

45. Hast, L. (1954). Monthly Report 54, SRCH, June 10, 1954.

46. Institute for Military History (1998). History of UN's Assistance. Seoul: Institute for Military History.

47. Inui, F-K., Shannon, J., and Howard, J-M. (1955). Arterial injuries in the Korean conflict; experiences with 111 consecutive injuries, Surgery 37, 850-857.

48. Jakobsen, P-V. (2016). Denmark and UN Peacekeeping: glorious past, dim future, International Peacekeeping 23 (5), 757-758. 
49. Jakobsen, P-V. (2016). Denmark and UN Peacekeeping: glorious past, dim future, International Peacekeeping 23 (5), 745-746.

50. Jessen, C. (1953). Kirurgisk virksomhed på Jutlandia vinteren 1951-52, Anaestesien 115 (24), 932-934.

51. Kaijser, R. (1951). Monthly Report 19, SRCH, November 13.

52. Kapel, O. (1953). Kirurgisk virksomhed pa Jutlandia vinteren 1951-52.

53. Keene, R-R. (1991). Korea: 40 years ago this month: truce talks: the stalling begins, Quantico 74 (8), 54-57.

54. Kim, E. (2009). The origins of Korean adoption: Cold War geopolitics and intimate diplomacy, the U.S.-Korea Institute's Working Paper Series, 1-26.

55. Kim, S-S. (2014). "The evolving asian system: three transformations", in Shambaugh D-L. \&Yahuda M-B (Eds.) International Relations of Asia (45). Lanham: Rowman \& Littlefield.

56. Kin, B., and Jatoi, I. (2005). The mobile army surgical hospital (MASH): a military and surgical legacy, Journal of the National Medical Association 97 (5), 648.

57. Kok, F. (1996). Stena Jutlandica (deel 1), Schip en Werf de Zee, 38-47.

58. Kok, F. (1996). Stena Jutlandica (deel 2), Schip en Werf de Zee, 24-33.

59. Kolb, R-K (1999). In Korea we whipped the Russian air force, VFW Magazine 86 (11) [Online] http:// www.koreanwar-educator.org/topics/vfw/p_we_wipped_the_russian_af.htm (28 May 2021).

60. Koo Y. (2021). The question of adoption: "divided" korea, "neutral" Sweden, and Cold War geopolitics, 1964-75, Journal of Asian Studies, 1-23. doi:https://doi.org/10.1017/S0021911820004581.

61. Korean War Project, [Online] https://twitter.com/koreanwarvets (21 August 2020).

62. Krivošeev, G-F. (1997), Soviet Casualties and Combat Losses in the Twentieth Century. London: Greenhill.

63. Larsen, K. "Jutlandia", [Online] https://kjukken.dk/sang/jutlandia/ (30 July, 2020).

64. Lee, C. (2020). A study on the heritage interpretation of the United Nations Memorial Cemetery in Korea for the Inscription on the world heritage list- based on the funerary and memorial sites of the First World War (western front), Journal of Cultural Policy 34 (1), 159-186.

65. Li, X. (2007). A Histeory of the Modern Chinese Army. Lexington, KY: University Press of Kentucky.

66. Lippincott W. \&W. (1951). The Jutlandia: Home Port Copenhagen, American Journal of Nursing 51 (9), 543.

67. Lockertsen, J-T. (2018). The nursing legacy of the Korea sisters. Nursing Open 5 (1), 94-100.

68. Lockertsen, J-T. (2018). The nursing legacy of the Korea sisters. Nursing Open 5 (1), 95-96.

69. Lockertsen, J-T. (2018). The nursing legacy of the Korea sisters. Nursing Open 5 (1), 96.

70. Lockertsen, J-T. (2018). The nursing legacy of the Korea sisters. Nursing Open 5 (1), 97-98.

71. Lockertsen, J-T. (2018). The nursing legacy of the Korea sisters. Nursing Open 5 (1), 98.

72. Lockertsen, J-T., Fause, Å., and Hallett, C-E. (2020). The Norwegian Mobile Army Surgical Hospital in the Korean War (1951-1954): military hospital or humanitarian 'sanctuary?,' Nursing History Review 28, 95-96.

73. Lockertsen, J-T., Fause, Å., and Hallett, C-E. (2020). The Norwegian Mobile Army Surgical Hospital in the Korean War (1951-1954): military hospital or humanitarian 'sanctuary?,' Nursing History Review 28, 94-95.

74. Lockertsen, J-T., Fause, Å., and Hallett, C-E. (2020). The Norwegian Mobile Army Surgical Hospital in the Korean War (1951-1954): military hospital or humanitarian 'sanctuary?,' Nursing History Review 28, 93-126.

75. Lockertsen, J-T., Fause, Å., and Hallett, C-E. (2020). The Norwegian Mobile Army Surgical Hospital in the Korean War (1951-1954): military hospital or humanitarian 'sanctuary?,' Nursing History Review 28, 95-97.

76. Lockertsen, J-T., Fause, Å., and Hallett, C-E. (2020). The Norwegian Mobile Army Surgical Hospital in the Korean War (1951-1954): military hospital or humanitarian 'sanctuary?,' Nursing History Review $28,107$.

77. Lockertsen, J-T., Fause, Å., and Hallett, C-E. (2020). The Norwegian Mobile Army Surgical Hospital in the Korean War (1951-1954): military hospital or humanitarian 'sanctuary?', Nursing History Review $28,110$.

78. Lockertsen, J-T., Fause, Å., and Hallett, C-E. (2020). The Norwegian Mobile Army Surgical Hospital in the Korean War (1951-1954): military hospital or humanitarian 'sanctuary?,' Nursing History Review $28,104$.

79. Lockertsen, J-T., Fause, Å., and Hallett, C-E. (2020). The Norwegian Mobile Army Surgical Hospital in the Korean War (1951-1954): military hospital or humanitarian 'sanctuary?,' Nursing History Review $28,108$. 
80. Lockertsen, J-T., Fause, Å., and Hallett, C-E. (2020). The Norwegian Mobile Army Surgical Hospital in the Korean War (1951-1954): military hospital or humanitarian 'sanctuary?,' Nursing History Review $28,115$.

81. Lockertsen, J-T., Fause, Å., and Hallett, C-E. (2020). The Norwegian Mobile Army Surgical Hospital in the Korean War (1951-1954): military hospital or humanitarian 'sanctuary?,' Nursing History Review $28,116$.

82. Lockertsen, J-T., Fause, Å., and Hallett, C-E. (2020). The Norwegian Mobile Army Surgical Hospital in the Korean War (1951-1954): military hospital or humanitarian 'sanctuary?,' Nursing History Review $28,117$.

83. Maekyung Media Group. (2016). There will be a KORMASH in Korea (한국에도 이동외과병원 생긴다), [Online] https://www.mk.co.kr/news/it/view/ 2016/03/193768/ (14 March 2016).

84. Midtgaard, K. (2011). National security and the choice of international humanitarian aid: Denmark and the Korean War, 1950-1953, Journal of Cold War Studies 13 (2), 148-174.

85. Midtgaard, K. (2011). National security and the choice of international humanitarian aid: Denmark and the Korean War, 1950-1953, Journal of Cold War Studies 13 (2), 149-151.

86. Midtgaard, K. (2011). National security and the choice of international humanitarian aid: Denmark and the Korean War, 1950-1953, Journal of eCold War Studies 13 (2), 153-155.

87. Midtgaard, K. (2011). National security and the choice of international humanitarian aid: Denmark and the Korean War, 1950-1953, Journal of Cold Wear Studies 13 (2), 169-174.

88. Military medical advance resulting from the conflict in Korea, part ii: historic clinical accomplishments, Military Medicine 177 (4) (2012): 430-435.

89. Ministry of Health and Welfare (MHW). (2017). Statistics on International adoption, 1958-2016 (국제입양누적통계, 1958-2016), Seoul: MHW.

90. Ministry of National Defense (1980). History of the Korean War 11. Seoul, Ministry of National Defense.

91. Ministry of National Defense of Republic of Korea, (2013). "Casualties of Korean War (in Korean)", archived from the original document.

92. Ministry of Patriots and Veterans Affairs. "Historical Meaning" [Online] https://www.mpva.go.kr/ english /front/koreanwar/historical.do (30 June, 2020).

93. Mygind, O. (2013). Jutlandia. Skibet var ladet med håb, Ugeskrift for Laeger 175 (47), 2892-2894.

94. National Archives of Korea. (1950). Jutlandia, a United National Hospital Ship from Denmark (덴마 크에서 지원한 유엔병원선 유틀란디아 (Jutlandia)호), DTC0000005.

95. National Archives of Korea. (1982). The issue of establishing a national medical centre in South Koreea (대한민국에 국립메디칼센터), A0001982.

96. National Medical Centre. (2010). Illness Treatment 50 Years, Citizen Health 100 Years: 1958-2008 (질 병치료 50년, 국민건강 100년: 1958-2008). National Medical Centre: Seoul.

97. New motorship Jutlandia. (1935). Pacific Marine Review. San Francisco: J.S. Hines, XXXII (3).

98. Östberg, S-S. (2014). The Swedish Red Cross Hospital in Busan 1950-1958: a study of its transition from a military to a civilian hospital, Korea Journal 54 (1), 133-156.

99. Östberg, S-S. (2014). The Swedish Red Cross Hospital in Busan 1950-1958: a study of its transition from a military to a civilian hospital, Korea Journal 54 (1), 136.

100. Östberg, S-S. (2014). The Swedish Red Cross Hospital in Busan 1950-1958: a study of its transition from a military to a civilian hospital, Korea Journal 54 (1), 140.

101. Östberg, S-S. (2014). The Swedish Red Cross Hospital in Busan 1950-1958: a study of its transition from a military to a civilian hospital, Korea Journal 54 (1), 142.

102. Östberg, S-S. (2014). The Swedish Red Cross Hospital in Busan 1950-1958: a study of its transition from a military to a civilian hospital, Korea Journal 54 (1), 143.

103. Östberg, S-S. (2014). The Swedish Red Cross Hospital in Busan 1950-1958: a study of its transition from a military to a civilian hospital, Korea Journal 54 (1), 147-149.

104. Östberg, S-S. (2014). The Swedish Red Cross Hospital in Busan 1950-1958: a study of its transition from a military to a civilian hospital, Korea Journal 54 (1), 149-150.

105. Östberg, S-S. (2014). The Swedish Red Cross Hospital in Busan 1950-1958: a study of its transition from a military to a civilian hospital, Korea Journal 54 (1), 134-136.

106. Östberg, S-S. (2014). The Swedish Red Cross Hospital in Busan 1950-1958: a study of its transition from a military to a civilian hospital, Korea Journal 54 (1), 152-155.

107. Östberg, S-S. (2014). The Swedish Red Cross Hospital in Busan 1950-1958: a study of its transition from a military to a civilian hospital, Korea Journal 54 (1), 153-155.

108. Park, J. (2010). The medical assistance of Swedish Red Cross Field Hospital in Busan during and after the Korea War, Korean Journal of Medical History 19, 23-25. 
109. Park, J. (2010). The medical assistance of Swedish Red Cross Field Hospital in Busan during and after the Korea War, Korean Journal of Medical History 19, 193-194.

110. Park, J. (2010). The medical assistance of Swedish Red Cross Field Hospital in Busan during and after the Korea War, Korean Journal of Medical History 19, 190-193.

111. Park, J. (2010). The medical assistance of Swedish Red Cross Field Hospital in Busan during and after the Korea War, Korean Journal of Medical History 19, 200-208.

112. Puig, V. (2016). Otra Batalla de Jutlandia, Cuadernos de Pensamiento Político 50, 41-44.

113. Quoted from "United Nations Command", [Online] https://www.facebook.com/United NationsCommand/ (21 August 2020).

114. RAFA, B. (1951). File 3422, Hårvik Aslaug, Letter to Matron-in-Chief of September 29, 1951.

115. RAFA, B. (1954). File 3422, Ragnar Nordlie. Report from chief of hospital, NORMASH, to the general surgeon, the Norwegian Armed Forced Medical Services of April 7, 1954.

116. Ringsmore, J. (2009). Paying for protection: Denmark's military expenditure during the Cold War, Cooperation and Conflict 44 (1), 80-81.

117. Ringsmore, J. (2009). Paying for protection: Dnmark's military expenditure during the Cold War, Cooperation and Conflict 44 (1), 81-85.

118. Roelsgaard, M. (1953). Røntgenologisk virksomhed på Jutlandia, Ugeskrift for laeger 115 (24), 930932.

119. Rosmini, M. (2014). The philosophy of $\mathrm{M}^{*} \mathrm{~A} * \mathrm{~S} * \mathrm{H}$, Travel Medicine and Infection Disease 12, 412413.

120. Royal Norwegian Embassy in Seoul. "NORMASH” [Online] https://www.norway. no/en/south-korea/ norway-south-korea/normash/ (12 August 2020).

121. Rummel, R-J. (1997). "Statistics of North Korean democide estimates, calculations, and sources," in Rummel R-J. (Ed.), Statistics of Democide: Genocide and Murder Since 1900 (pp. 132-138). Münster: LIT Verlag.

122. Sarnecky, M-T. (1999). A History of the U.S. Army Nursee Corps. Philadelphia: University of Pennsylvania Press.

123. Schmidt, V. (1952). Medicinske indtryk fra hospitalsskibet Jutlandia, Militaerlaegen (01/12/1952): 99110 .

124. Schrijver, N. (2015). "Intervention, armed intervention, armed attack, threat to peace, act of aggression, and threat or use of force: what's the difference?", in Well, M. (Ed.), The Oxford Handbook of the Use of Force in International Law (1 ed.) (p. 494). Oxford: Oxford University Press; Klabbers J.

125. Schrijver, N. (2015). "The ban on the use of force in the UN charter", in Well, M. (Ed.), The Oxford Handbook of the Use of Force in International Law (1 ed.) (p. 478). Oxford: Oxford University Press; Klabbers J.

126. Shrader, C-R (1995). Communist Logistics in the Korean War. Issue 160 of Contributions in Military Studies. Santa Barbara, California: Greenwood Publishing Group).

127. Sibu, E-A. (2011). Medical railroading during the Korea War 1950-1953, Railroad History (SpringSummer), 49-65.

128. Status of the interred at the UNMCK, [Online] https://www.unmck.or. kr:450/eng/02_unmck/?mcode= 0502010300 (21 July 2020).

129. Stokesbury, J-L. (1990). A Short History of the Korean War. New York: Harper Perennial.

130. Stueck, W-W. (1995). The Korean War: An International History (1st ed.). Princeton, New Jersey: Princeton University Press.

131. Swedish Red Cross, Monthly Reports from Dr. Aino Vainola to the Korea (Stockholm).

132. The Economic Times (2020). Forgotten tales of courage and valour: the bucket brigade. July 09, 2020 [Online] https://economictimes.indiatimes.com/news/defence/forgotten-tales-of-courage-and-valourthe-bucket-brigade/articleshow/76872936.cms?from=mdr (28 May 2021).

133. The Korea Times (Hankook Ilbo) (2020). It seems that the number of COVID-19 decreased in Seoul (수도권 코로나19 증가세 꺾인 듯). 25 August 2020 [Online] https://www.hankookilbo. com/News/Read/ A2020082511530001003 (21 March 2020).

134. There will be a KORMASH in Korea (한국에도 이동외과병원 생긴다), [Online] https:/www.mk.co.kr/ news/it/view/ 2016/03/193768/ (14 March 2016).

135. Thyssen, J. (1953). Thorax-kirurgisk virksomhed på Jutlandia vinteren 1951-52.

136. Tornqvist, S. (1956). Appendix, Monthly Report 54, SRCH, March 2, 1956.

137. United Nations Korean Reconstruction Agency. (1956). Agreement (with Annex) for the Establishment and Operation of a National Medical Centre in Korea. No. 6158 (United Nations Treaty Series. s.l.: United Nations) 
138. United Nations Memorial Cemetery in Korea. Interred at the UNMCK, [Online] https://www.unmck.or. $\mathrm{kr} / \mathrm{eng} / 04 \mathrm{memory} /$ ?mcode $=0504010000$ (13 August 2020).

139. Wellens, K-C (Ed.) (1990). Resolutions and Statements of the United Nations Security Council: (19461989); a Thematic Guide. Dordrecht: Brill.

140. Wille, H. (1953). Jutlandia's 3. togt til Korea. V. Jutlandia's nye ojenafdeling, Ugeskrift for laeger 115 (7) $(12 / 02), 263-264$.

141. Wilson, K-L., Debeatham, W-L., Danner, O-K., Ray, M-L., Bacon, L-N., and Weaver, W-L. (Eds.) (2012). The forgotten MASH surgeon: the story of alvin vincent blount Jr, MD, Journal of the National Medical Association 104 (3\& 4), 221-413.

142. Wilson, K-L., Debeatham, W-L., Danner, O-K., Ray, M-L., Bacon, L-N., and Weaver, W-L. (Eds.) (2012). The forgotten MASH surgeon: the story of alvin vincent blount Jr, MD, Journal of the National Medical Association 104 (3\& 4), 221.

143. Winge, M. (1961). Nordic military medical activity in a foreign milieu: the hospital ship Jutlandia, Tidskrift i militär hälsovård 86 (01/01/1961), 229-238.

144. Woodard, S-C. (2003). The story of the mobile army surgical hospital, Military Medicine 168 (7), 503513.

145. Yoon, J-Y. (2016). NMC chief thanks veterans of Jutlandia, The Korea Times; Seoul 25 Jan 2016.

146. Young, C., Conard, P-L., Armstrong, M-L., and Lacy, D. (Eds.) (2018). Older military veteran care: many still believe they are forgotten, Journal of Holistic Nursing 36 (3), 291-300.

147. Young, S-M. (2010). Israel's role in the UN during the Korean War, Israel Journal of Foreign Affairs 4 (3): 81-89.

148. Yun, H. (1956), Daecheon Diary (대천일기), 7 June 1956.

149. Yun, H. (1956), Daecheon Diary (대천일기), 7 June 1956. 65-67.

Publisher's Note Springer Nature remains neutral with regard to jurisdictional claims in published maps and institutional affiliations. 